\title{
Correction to: A Perfect Storm? Health Anxiety, Contamination Fears, and COVID-19: Lessons Learned from Past Pandemics and Current Challenges
}

Danielle Dennis $^{1,2} \cdot$ Cynthia Radnitz $^{1} \cdot$ Michael G. Wheaton ${ }^{2}$

Published online: 8 June 2021

(C) Springer Nature Switzerland AG 2021

Correction to: International Journal of Cognitive Therapy (2021) https://doi.org/10.1007/s41811-021-00109-7

This erratum is to update the reference list and ensure the references are in the correct alphabetical order.

The original article has been corrected.

Publisher's Note Springer Nature remains neutral with regard to jurisdictional claims in published maps and institutional affiliations.

The online version of the original article can be found at https://doi.org/10.1007/s41811-021-00109-7

Danielle Dennis

dbd2110@student.fdu.edu

1 Fairleigh Dickinson University, Teaneck, NJ, USA

2 Barnard College of Columbia University, New York City, NY, USA 